\title{
Numbers and biomass of soil invertebrates in a reserved field in central Finland
}

Tiмo TöRMÄLÄ

Department of Biology, ${ }^{1}$ University of Jyväskylä, Yliopistonkatu 9 40100 Jyväskylä 10

and

Institute of Ecology, Polish Academy of Sciences, Warsaw

\begin{abstract}
The numbers and biomasses of soil invertebrates were investigated in a reserved field in central Finland. Samples were taken monthly from June to September. Five methods were employed to extract the animals from the soil samples. The animals were counted, measured and their dry biomasses were estimated by body length/weight regressions and dry weight/wet weight ratios derived from the literature. In July the total biomass of the soil invertebrate community (excluding Protozoa, Tardigrada and Rotatoria) was about $9.6 \mathrm{~g}$ dry weight $\mathrm{m}^{-2}$. The most dominant groups were Lumricidae $(73.1 \%)$, Enchytraeidae $(5.7 \%)$, Oribatei $(5.0 \%)$, and Nematoda $(4.4 \%)$. In September the biomass of Diptera larvae was high $\left(1.0 \mathrm{~g} \mathrm{dw} \mathrm{m}^{-2}\right)$. In numbers nematodes were superior (maximum 12 million $\mathrm{m}^{-2}$ ) to other groups.

Oribatei, Mesostigmata and Collembola were more concentrated to the soil surface than other Acari, Enchytraeidae and Nematoda. The mean individual size decreased with depth in all of the studied groups.
\end{abstract}

\section{Introduction}

During the last fifteen years far more quantitative studies of soil animals have been published than earlier. The main reason for this is, in addition to the better understanding of the importance of soil animals in litter break-down processes, in the rapid developement and evaluation of extraction methods (e.g. Phillipson 1971).

The almost total death of above-ground vegetation in the autumn is characteristic of temperate grasslands. This organic material together with dead parts of underground vegetation is the primary energy source for decomposers living in litter and soil. The actual decomposition of organic compounds is mostly performed by soil bacteria, fungi and other microorganisms, which in turn are an important source of food to soil animals (BURGES and RAw 1967).

1) Present adress 
Reserved fields (for background see HokKanen and RaAtikainen 1977, TÖRMÄLÄ 1977, HOKKANEN 1979) differ fundamentally from fields in agricultural use, e.g. pastures and fields for hay, because the primary production is not harvested and transferred outside the ecosystem. Thus the amount of organic material available to decomposers is much higher in reserved fields and natural grassland habitats than in managed grasslands of equal productivity.

The soil fauna of grasslands has been investigated within the framework of the International Biological Programme e.g. in Sweden (Persson and LoHM 1977), Poland (Nowak 1971, 1975, Wasilewska 1974) and USA (Crossley et al. 1975). In Finland quantitative information about the soil fauna is available only of forest ecosystems (Huhta et al. 1967, Huhta and Koskenniemi 1975) and different kinds of sewage sludge and crushed bark mixtures (Huнta et al. 1977, in print).

This paper forms a part of studies on reserved fields initiated in 1973 at the University of Jyväskylä. It aims to give a general picture of the quantity of different soil animal groups in a typical reserved field in central Finland.

\section{Material and methods}

Study site

The sampling was performed in a reserved field, Ruokepuolinen, in the rural commune of Jyväskylä $\left(62^{\circ} 14^{\prime} \mathrm{N}, 25^{\circ} 36^{\prime} \mathrm{E}\right)$ in 1976 . The field had been uncultivated and unmanaged for seven years. The vegetation was dominated by Achillea ptarmica, Poa pratensis, Agrostis tenuis, and Deschampsia caespitosa. For detailed information about primary production and the dynamics of the vegetation and fauna of the field stratum see TÖRMÄLÄ and RAATIKAINEN (1976). The vegetation and field stratum fauna were also sampled in 1978 (TöRMÄL $\ddot{A}$ in prep.).

The weather data, based on observations made at Jyväskylä airport some $15 \mathrm{~km}$ north of the study site, are presented in Table 1 .

Table 1. Weather data for thirty days preceding each sampling date (ANon. 1976).

\begin{tabular}{cllll}
\hline Period & \multicolumn{1}{c}{$18.05 .-17.06}$. & $19.06 .-18.07$. & $19.07 .-17.08$. & $18.08 .-16.09$. \\
\hline Mean temperature ${ }^{\circ} \mathrm{C} \ldots \ldots$. & 10.6 & 13.3 & 15.1 & 10.4 \\
Rainfall mm ................ & 21.8 & 81.3 & 73.6 & 92.1 \\
No. of rainy days .......... & 13 & 21 & 13 & 18 \\
\hline
\end{tabular}

\section{Sampling}

Ten sampling plots were chosen at random from the 0.6 ha study field. Each plot $(10 \times 5 \mathrm{~m})$ was sampled on 18 June, 19 July, 18 August, and 17 September. An area of one square meter was selected from each plot by random tables for the actual sampling.

Samples for analyzing the physical properties of the soil were taken with a corer of the type described e.g. by Persson and Lohm (1977). The plastic 
rings inside the corer which allow a convenient division of samples to vertical fractions were three $\mathrm{cm}$ high. The corer took samples from an area of $9.51 \mathrm{~cm}^{2}$. Samples from the layers $0-3 \mathrm{~cm}$ and $6-9 \mathrm{~cm}$ were taken each time. On 19 July and 17 September additional samples down to $15 \mathrm{~cm}$ were taken from five of the plots.

Microarthropods (Acari and Collembola) and Nematoda were taken with the same corer as the physical samples. Usually only the layers $0-3 \mathrm{~cm}$ and $6-9 \mathrm{~cm}$ were sampled, but on 19 July samples from $3-6,9-12$, and $12-15$ $\mathrm{cm}$ were also taken from five of the plots. The sampling procedure for Enchytraeidae was the same but the area of the corer was $24.15 \mathrm{~cm}^{2}$. Macroscopic arthropods and Lumbricidae were sampled from an area of $625 \mathrm{~cm}^{2}$ to a depth of eight $\mathrm{cm}$ by a spaddle described by HuHTA et al. (1967).

\section{Physical determinations}

The soil samples inside the plastic rings were put in tight plastic bags in the field and transported to the laboratory, where they were immediately weighed to the nearest $0.01 \mathrm{~g}$. The samples were then dried in $105^{\circ} \mathrm{C}$ for 24 hours to determine the water-free wight. Loss on ignition (organic content) was measured after keeping the samples in an oven $\left(550^{\circ} \mathrm{C}\right)$ for four hours.

\section{Extraction techniques}

The extraction of nematodes followed the modified OosTENBRINK (1960) cotton wool filter method described by HuHta and Koskenniemi (1975) with the following exceptions: the original soil sample $\left(9.51 \mathrm{~cm}^{2} \times 3 \mathrm{~cm}\right)$ was mixed with a Vibromixer in one liter of water. The subsample for the actual filtration was only 0.051 because of the great number of nematodes. The lower samples were filtrated with 0.11 of the suspension. Decantation was performed because of the high mineral content of the soil.

Wet funnel technique (O'Connor 1962) was employed for Enchytraeidae. This method is efficient and requires much less laboratory work than NiELSEN's (1955 a) method.

Earthworms were extracted with the large wet funnel described by HuHTA and Koskenniemi (1975). This method is much easier and more efficient especially for small worms than hand-sorting, and it proved to be suitable for the soil type of the study field.

Acari and Collembola were taken from the samples by an infrared highgradient extractor originally described by LUSSENHOP (1971) and later modified by Huhta and Koskenniemi (1975). The water bath was kept at a desired temperature with a compressor connected to a thermostat.

Larger arthropods were extracted with closed Tullgren funnels described by Huhta (1972).

\section{Estimation of biomass}

The extracted animals were identified, counted and their body lengths were measured. The nematodes were measured alive in water, other groups in 70 per cent alcohol. Large animals were measured against the lines $(2 \mathrm{~mm}$ 
apart) of the counting dish and small ones by means of an ocular grid of the binocular microscope. The length was not determined absolutely but the animals were placed to the nearest of the following size categories: $0.1,0.15$, $0.2,0.3,0.4,0.5,0.6,0.8,1.0,1.2,1.5,2.0,3,4,5,6,8,10,12,15,20$, $30,40,50,60,70,80,100$, and $120 \mathrm{~mm}$.

For Coleoptera dry weights for each species (Koskela and Hanski 1977) or length/dry weight regressions (Koskela, unpublished) were employed. The biomass of Coleoptera and Diptera larvae was estimated by length/dry weight regressions specific to each family (Koskela, unpublished).

The dry biomass of the remaining groups was determined by the following procedure: by the length of animals wet weights were obtained and these were converted to dry weights (Table 2). The conversion of wet weights to dry ones may lead to under- or overestimates because a single conversion factor was used for each of the wide taxonomic units. This procedure was, however, considered necessary since dry weights provide a more sound basis for comparisons between and within the ecosystems.

Table 2. Constant $\mathrm{a}$ and $\mathrm{b}$ for the regression equation $\log \mathrm{Y}=\operatorname{blog} \mathrm{X}+\mathrm{a}$ for wet weights. $\mathrm{Y}$ is the wet weight (in $\mu \mathrm{g}$ ) and $\mathrm{X}$ is the length of an animal in $\mathrm{mm}$. $\mathrm{c}$ is the conversion factor from wet to dry weights. In brackets is the base of the logarithm in the equations.

\begin{tabular}{|c|c|c|c|}
\hline Taxon & b & a & c \\
\hline Nematoda $\quad$............................................ & $1.87^{2}(\mathrm{e})$ & $-0.71^{2}$ & $0.25^{3}$ \\
\hline Enchytraeidae .................................... & $1.83^{2}(\mathrm{e})$ & $1.84^{2}$ & $0.18^{3}$ \\
\hline Allolobophora caliginosa $(\mathrm{mg})$................. & $2.07^{4}(10)$ & $-2.55^{4}$ & $0.18^{3}$ \\
\hline Other Lumbricidae $(\mathrm{mg})$........................ & $2.07^{4}(10)$ & $-2.44^{4}$ & $0.18^{3}$ \\
\hline 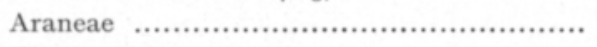 & $3.43^{1}(10)$ & $1.88^{1}$ & $0.27^{5}$ \\
\hline 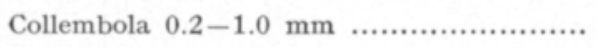 & $2.43^{1}(10)$ & $1.31^{1}$ & $0.35^{3}$ \\
\hline c. $1.2-3.0 \mathrm{~mm}$ & $2.42^{1}(10)$ & $1.49^{1}$ & $0.35^{3}$ \\
\hline 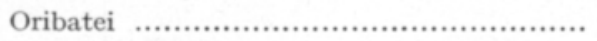 & $2.51^{1}(10)$ & $2.38^{1}$ & $0.40^{6}$ \\
\hline 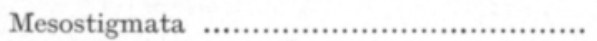 & $3.23^{2}(\mathrm{e})$ & $5.04^{2}$ & $0.40^{6}$ \\
\hline 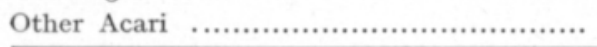 & $2.06^{1}(10)$ & $1.46^{1}$ & $0.40^{6}$ \\
\hline
\end{tabular}

1) Huhta and Koskenniemr 1975, ${ }^{2}$ ) Huhta et al. in print, ${ }^{3}$ ) Edwards 1967, ${ }^{4}$ ) Abrahamsen 1973, ${ }^{5}$ ) Edgar 1971, 6) Person and Lohm 1977.

\section{Results}

Soil

Soil moisture together with temperature is the most important factor causing fluctuations in the populations of soil animals. In this study soil moisture is expressed as percentage of water in the volume (Table 3, Fig. 1). The data are not very relevant because they only indicate the situations on the sampling dates. The soil was driest in July and August. The sampling on 19 July was preceded by 13 rainless days. Changes in soil moisture did not seem to be as sharp in the deeper layer as in the upper one (Fig. 1). 
Table 3. Bulk density, organic content and amount of water in the soil of the study field on 17 September.

\begin{tabular}{|c|c|c|c|c|c|c|c|c|c|}
\hline & \multicolumn{2}{|c|}{ Bulk density } & \multicolumn{2}{|c|}{ Organic content } & \multirow[b]{2}{*}{$\%$} & \multirow[b]{2}{*}{ S.E. } & \multicolumn{2}{|c|}{ Water of volume } & \multirow[t]{2}{*}{$\mathrm{n}$} \\
\hline Depth $\mathrm{cm}$ & $\mathrm{g} / \mathrm{cm}^{3} \mathrm{dw}$ & S.E. & $\mathrm{g} / \mathrm{cm}^{3} \mathrm{dw}$ & S.E. & & & $\%$ & S.E. & \\
\hline $0-3$ & 0.66 & 0.06 & 0.099 & 0.005 & 15.00 & 2.00 & 55.09 & 1.96 & 10 \\
\hline $3-6$ & 1.02 & 0.04 & 0.089 & 0.004 & 8.73 & 0.92 & 51.57 & 2.06 & 5 \\
\hline $6-9$ & 1.11 & 0.04 & 0.090 & 0.010 & 8.10 & 1.07 & 50.09 & 2.03 & 10 \\
\hline $9-12$ & 1.12 & 0.11 & 0.087 & 0.011 & 7.76 & 2.41 & 49.44 & 2.82 & 5 \\
\hline $12-15$ & 1.12 & 0.03 & 0.082 & 0.005 & 7.32 & 0.70 & 50.84 & 1.87 & 5 \\
\hline
\end{tabular}

The mineral content in the soil of the study field was quite high especially in the lower layers. The organic material in Table 3 includes, in addition to detritus and humus, the living component of the soil.

The vertical distribution of organic material was surprisingly even in absolute amounts while the percentage of organic material decreased with depth (Table 3). From 6 to $15 \mathrm{~cm}$ there were no changes in the bulk density of the soil.

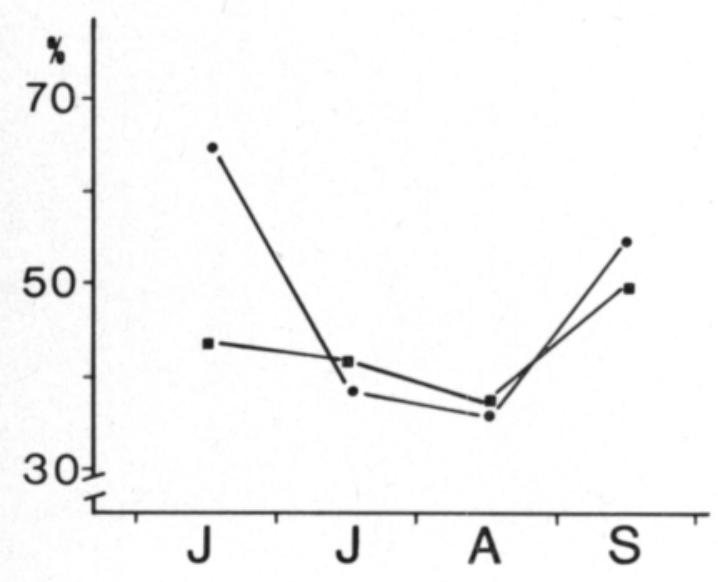

Fig. 1. Percentage of water of the soil volume in $0-3 \mathrm{~cm}$ and $6-9 \mathrm{~cm}$

\section{Vertical distribution}

The division of animals to above- and below-ground components is often arbitrary. Firstly, many animals use different horizons in different seasons or stages of their life cycle. Secondly, there is not usually any clear dividing line between the litter and the actual soil. In this study, litter was included in the samples and the division of animals was done on a taxonomical basis. For example the Tullgren funnel extraction gave many other animals (Homoptera, Heteroptera, herbivorous Coleoptera, etc.) in addition to those included in this report. But as they were known to be herbivorous or/and to live mostly in the field stratum they were ignored. Protozoa, Rotatoria and Tardigrada, which belong to the actual soil fauna, were neglected because the filtration method is unsuitable or at least questionable for these groups.

The sampling procedure employed allows an analysis of the vertical distribution of Nematoda, Enchytraeidae and microathropods. Seasonal changes 
in vertical distribution of these groups, expressed as the percentage of the number or biomass in $6-9 \mathrm{~cm}$ from that in $0-3 \mathrm{~cm}$, show a common feature: low values in August and/or September (Fig. 2). This indicates that the animals were at that time more concentrated to the surface layer of the soil. The greatest seasonal variation occurred in Enchytraeidae, of which there were very few in $6-9 \mathrm{~cm}$ on 17 September. Seasonal variation in vertical distribution was small in Collembola, Oribatei and Mesostigmata.

On 19 July a more precise sampling was performed in order to compare the vertical distribution of different groups of animals. It should be noted that the results are strictly valid only for that particular sampling day, since, as shown above, seasonal changes in vertical distribution were not synchronized in the groups studied.

Oribatei, Mesostigmata and Collembola concentrated to the surface of the soil (Fig. 3). E.g. $99 \%$ of the biomass and $88 \%$ of the numbers of Oribatei were in the uppermost three centimeters. The Nematoda, Enchytraeidae and other Acari had a more even vertical distribution. Only $\mathbf{5 8} \%$ of the biomass and $48 \%$ of the numbers of other Acari were in $0-3 \mathrm{~cm}$.

On comparing the curves based on numbers and biomasses within the animal groups (Fig. 2 and 3), one finds that their shapes are different. Generally, the biomasses were more concentrated to the upper layers than the numbers. Fig. 4 clearly demonstrates that the mean individual weight decreases with depth in all of the animal groups studied. The phenomenon is most explicit in Oribatei and Mesostigmata and least in Nematoda.

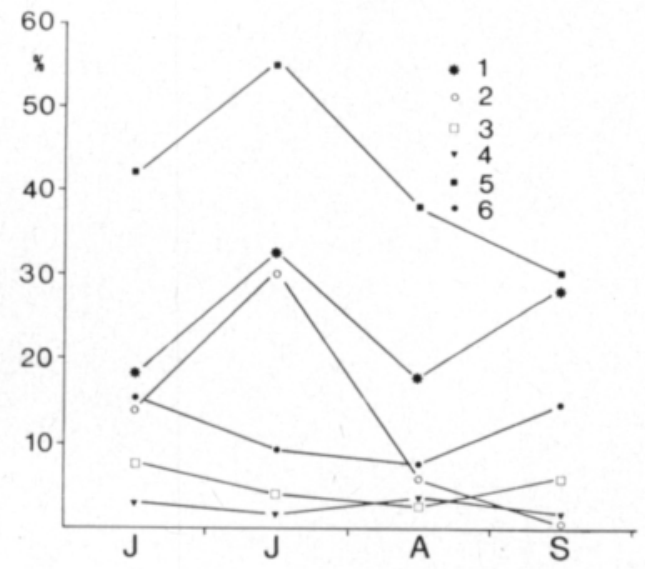

(a)

Fig. 2. Percentage of numbers (a) and biomasses (b) of some soil animal groups in $6-9 \mathrm{~cm}$ of the amount in $0-3 \mathrm{~cm}$.

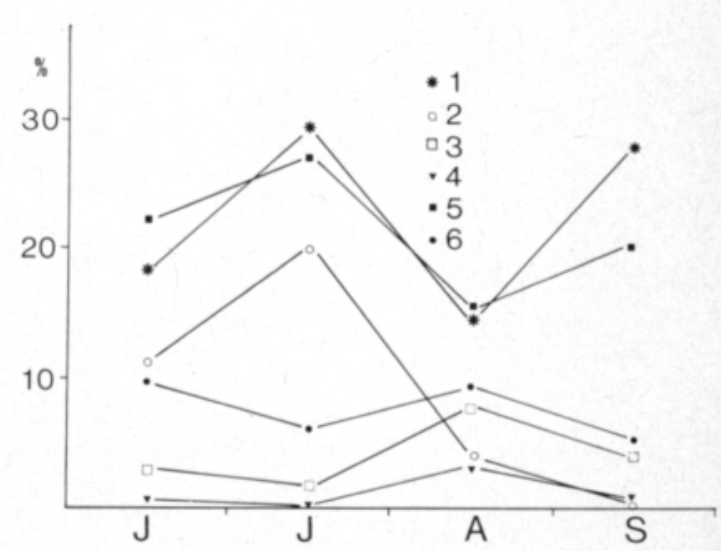

(b)

1. Nematoda, 2. Enchytraeidae, 3. Mesostigmata, 4. Oribatei, 5. Other Acari, 6. Collembola.

\section{Numbers and biomasses}

The densities and biomasses of the soil invertebrates are given in Tables 4-6. Figures from different sampling dates were not compared statistically because the vertical distribution was satisfactorily examined only on 19 July. 


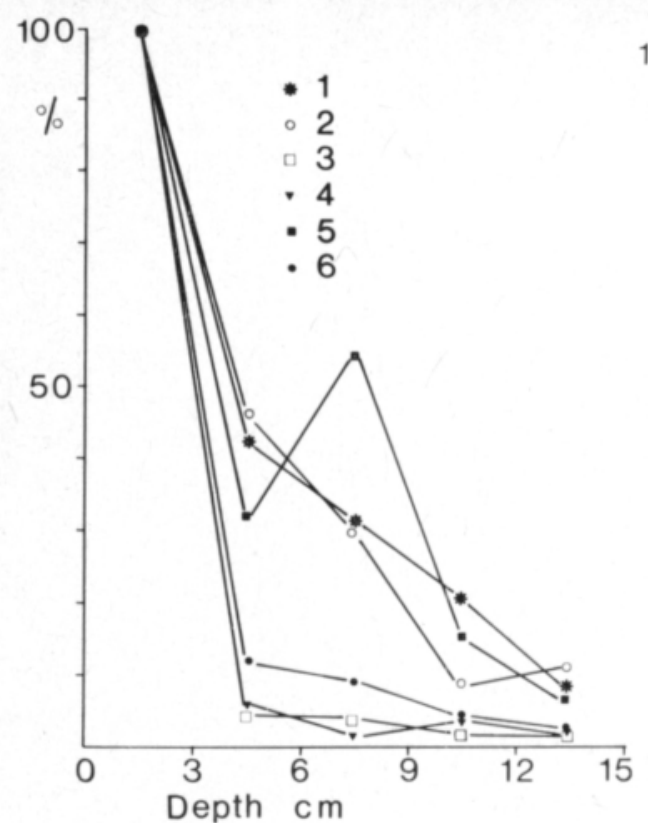

(a)

Fig. 3. Vertical distribution of numbers (a) and biomasses (b) of some soil animal groups on 19 July. Amount in

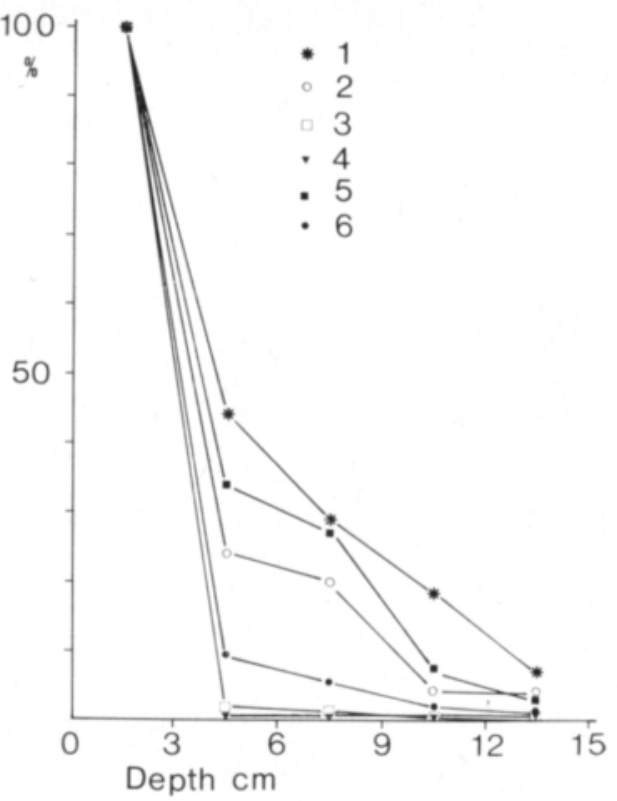

(b)

$0-3 \mathrm{~cm}$ is $100 \%$. 1. Nematoda, 2 . Enchytraeidae, 3. Mesostigmata, 4. Oribatei, 5. Other Acari, 6. Collembola.

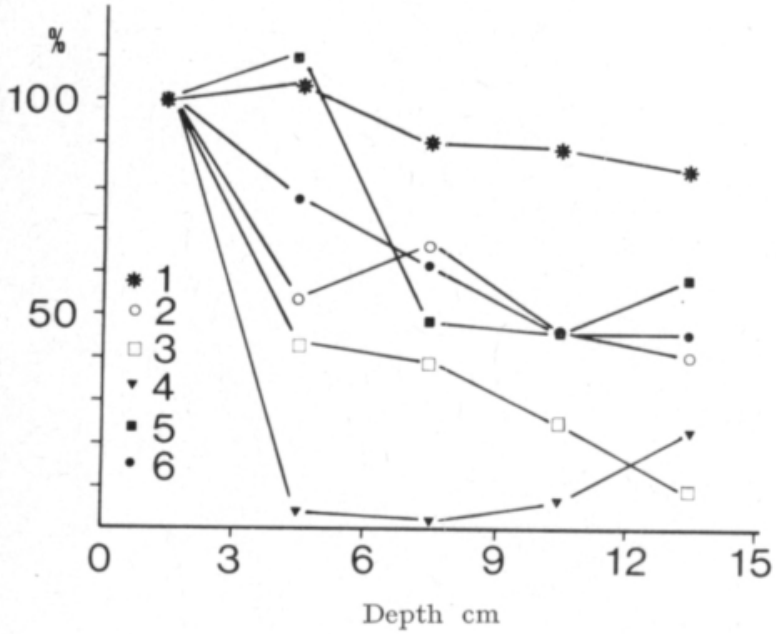

Fig. 4. Mean individual weight in some soil animal groups on 19 July as a function of depth. Weight in $0-3 \mathrm{~cm}$ is $100 \%$.

1. Nematoda, 2. Enchytraeidae,

3. Mesostigmata, 4. Oribatei, 5. Other Acari 6. Collembola.

Obvious trends an rough estimates for total abundances and biomassesd will be, however, given below. No corrections were made in the figures to cover the possible losses during sampling and extraction.

Nematoda was clearly the most numerous of the groups studied and if one takes in account the worms living below the sampling depth $(15 \mathrm{~cm})$ their number was about $12000000 \mathrm{~m}^{-2}$ on $19 \mathrm{July}$. On other sampling dates they amounted to $6-8$ million $\mathrm{m}^{-2}$. Their biomass ranged from about 250 to 450

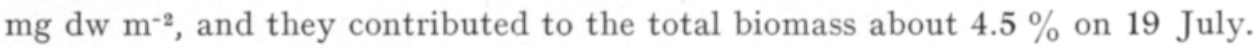




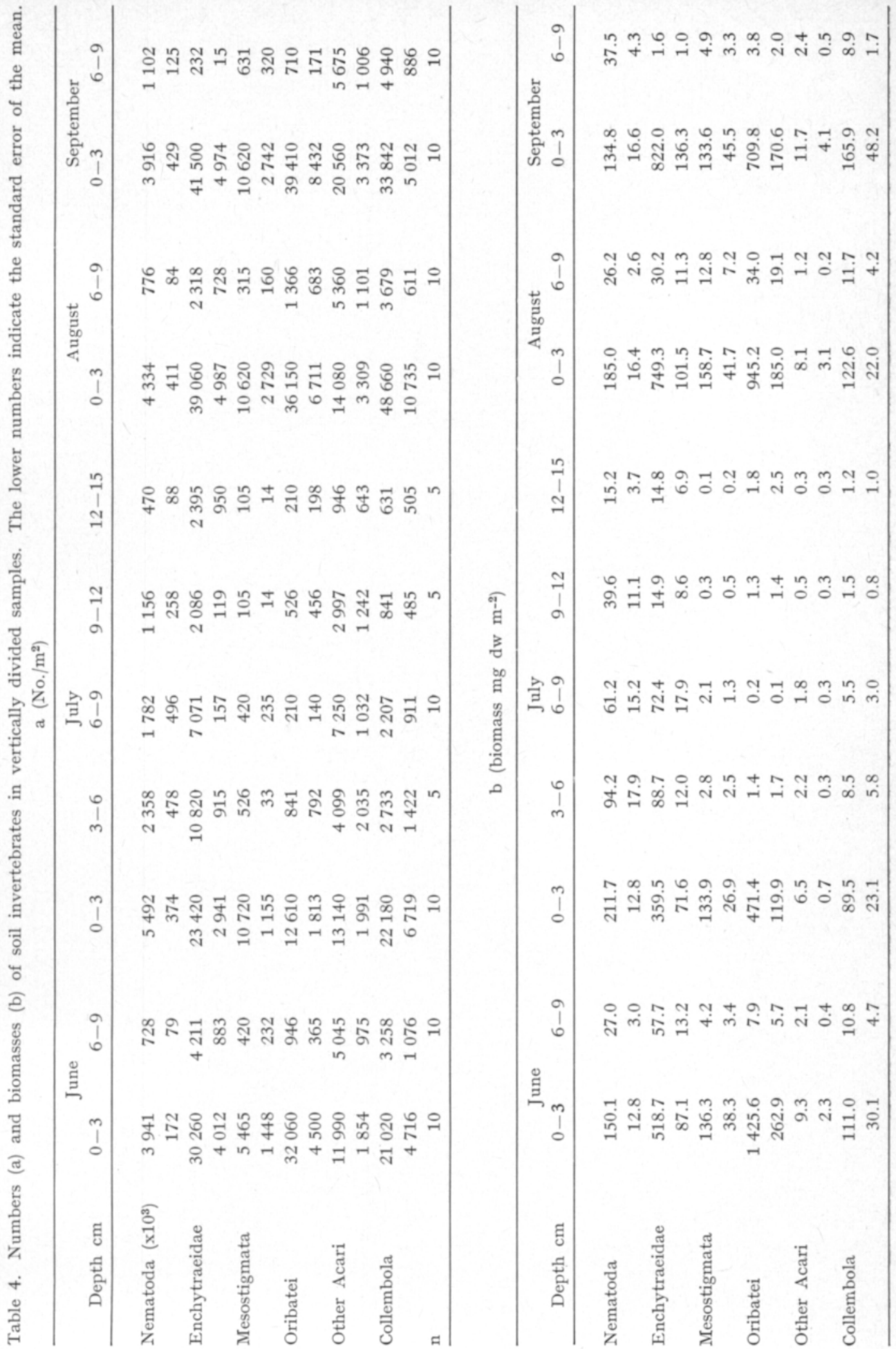


Table 5. Numbers and biomasses of soil invertebrates in samples that were not divided vertically. Sampling depth was $8 \mathrm{~cm}$. The lower figures indicate the standard error of the mean.

\begin{tabular}{|c|c|c|c|c|c|c|c|c|}
\hline \multirow{2}{*}{ Taxon } & \multicolumn{2}{|c|}{ June } & \multicolumn{2}{|c|}{ July } & \multicolumn{2}{|c|}{ August } & \multicolumn{2}{|c|}{ September } \\
\hline & No. $/ \mathrm{m}^{2}$ & $\mathrm{mg} / \mathrm{m}^{2}$ & No. $/ \mathrm{m}^{2}$ & $\mathrm{mg} / \mathrm{m}^{2}$ & No. $/ \mathrm{m}^{2}$ & $\mathrm{mg} / \mathrm{m}^{2}$ & No. $/ \mathrm{m}^{2}$ & $\mathrm{mg} / \mathrm{m}^{2}$ \\
\hline Dendrobaena & 297.6 & 1941 & 270.4 & 5479 & 184.0 & 3492 & 198.4 & 2119 \\
\hline octoedra & 23.5 & 231 & 38.8 & 763 & 31.0 & 674 & 27.6 & 337 \\
\hline Allolobophora & 25.6 & 1941 & 27.2 & 943.5 & 49.6 & 639.9 & 25.6 & 754.4 \\
\hline caliginosa & 8.7 & 810 & 7.2 & 467.4 & 16.1 & 223.0 & 5.9 & 324.8 \\
\hline Lumbricus & - & - & - & - & 22.4 & 2896 & 24.0 & 1172 \\
\hline rubellus & - & - & - & - & 9.3 & 1396 & 5.5 & 389 \\
\hline Octolaesium & 9.6 & 2625 & 3.2 & 585.3 & - & - & - & - \\
\hline lacteum & 6.4 & 2626 & 2.1 & 389.5 & - & - & - & - \\
\hline Lumbricidae & 332.8 & 6507 & 300.0 & 7008 & 256.0 & 7024 & 248.0 & 4046 \\
\hline total & 27.1 & 2758 & 39.5 & 1090 & 45.4 & 2050 & 29.7 & 737 \\
\hline \multirow[t]{2}{*}{ Araneae } & 371.2 & 33.8 & 307.2 & 26.0 & 542.4 & 107.8 & 260.8 & 43.9 \\
\hline & 42.1 & 6.9 & 45.1 & 3.4 & 155.9 & 32.0 & 31.7 & 11.1 \\
\hline \multirow[t]{2}{*}{ Coleoptera } & 217.6 & 149.5 & 233.6 & 216.1 & 198.4 & 151.7 & 220.8 & 185.7 \\
\hline & 34.4 & 30.4 & 43.5 & 44.2 & 37.6 & 48.1 & 51.5 & 66.2 \\
\hline \multirow[t]{2}{*}{ C. larvae } & 697.6 & 349.9 & 470.4 & 286.2 & 268.8 & 332.0 & 344.4 & 184.4 \\
\hline & 84.1 & 123.8 & 48.9 & 71.0 & 30.5 & 260.7 & 59.4 & 41.7 \\
\hline Nematocera & 148.8 & 26.3 & 1414 & 241.0 & 225.6 & 143.7 & 300.8 & 813.9 \\
\hline larvae & 30.3 & 22.1 & 909 & 185.0 & 72.6 & 53.1 & 53.4 & 524.1 \\
\hline Brachycera & 110.4 & 78.6 & 139.2 & 98.7 & 112.0 & 151.9 & 72.0 & 229.8 \\
\hline larvae & 25.3 & 46.6 & 26.5 & 34.0 & 21.5 & 53.1 & 11.7 & 91.7 \\
\hline
\end{tabular}

Table 6. Numbers and biomasses of soil invertebrates on 19 July in the reserved field. Sampling depth for Lumbricidae and macroarthropoda $8 \mathrm{~cm}$ and for other groups $15 \mathrm{~cm}$.

\begin{tabular}{|c|c|c|c|c|}
\hline Taxon & No. $/ \mathrm{m}^{2}$ & $\%$ & $\mathrm{mg} \mathrm{dw} / \mathrm{m}^{2}$ & $\%$ \\
\hline Nematoda ...................... & 11260000 & 98.83 & 422.2 & 4.41 \\
\hline Enchytraeidae $\ldots \ldots \ldots \ldots \ldots \ldots$ & 47000 & 0.42 & 550.3 & 5.74 \\
\hline Lumbricidae .................... & 300 & 0.00 & 7008.0 & 73.14 \\
\hline Aranaea ........................... & 307 & 0.00 & 26.0 & 0.27 \\
\hline Mesostigmata ................ & 11880 & 0.10 & 139.3 & 1.45 \\
\hline 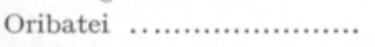 & 14400 & 0.13 & 476.1 & 4.97 \\
\hline Other Acari . .................... & 27430 & 0.24 & 11.3 & 0.12 \\
\hline Collembola ...................... & 28590 & 0.25 & 106.2 & 1.11 \\
\hline Coleoptera ...................... & 233 & 0.00 & 216.1 & 2.26 \\
\hline c. larvae ..................... & 470 & 0.00 & 286.2 & 2.99 \\
\hline Diptera larvae ................. & 1553 & 0.01 & 339.7 & 3.54 \\
\hline Total …........................... & 11392525 & 100.00 & 9581.6 & 100.00 \\
\hline
\end{tabular}

The number of Enchytraeidae varied during the summer around $50000^{2}$ $\mathrm{m}^{-2}$. Their biomass was greatest in August and September, $1.0-1.2 \mathrm{~g} \mathrm{dw} \mathrm{m}$., while in July it was only about $0.6 \mathrm{~g} \mathrm{dw}^{-2}$.

Four lumbricid species were found in the study field, namely Allolobophora caliginosa (Sav.), Dendrobaena octoedra (Sav.), Lumbricus rubellus Hoffm., and Octolaesium lacteum Örley. The total number of earthworms decreased to- 
wards the autum and their biomass also was lowest in September in the upmost $8 \mathrm{~cm}$. Because some very large specimens occurred in clumps the S. E. of the biomass estimates are big. In numbers $D$. octoedra was superior to the other species $(72-90 \%)$. This small species covered $30-70 \%$ of the total biomass of earthworms. L. rubellus and $O$. lacteum were met only on two sampling dates. The total biomass of Lumbricidae probably exceeded $10 \mathrm{~g} \mathrm{dw} \mathrm{m}^{-2}$ during maximum. They contributed $73 \%$ to the total biomass of soil animals on 19 July.

The number of Araneae varied between 260 and $542 \mathrm{~m}^{-2}$. Most of the specimens at the maximum on 18 August seemed to belong to a single species. The biomass of spiders ranged from 26 to $108 \mathrm{mg} \mathrm{dw}^{-2}$.

The abundance and biomass of adult Coleoptera were fairly constant throughout the summer. Coleoptera larvae were most abundant in June.

Nematocera larvae were on every sampling date more numerous than Brachycera larvae. The biomasses were more equal but in the last sampling Nematocera was superior to Brachycera. On 17 September the total biomass of the Diptera larvae was as high as $1.0 \mathrm{~g} \mathrm{dw}^{-2}$.

Springtails had their maximal density in August (ca. $60000 \mathrm{~m}^{-2}$ ). On other sampling occasions their number was about $30000-50000 \mathrm{~m}^{-2}$. The peak biomass of Collembola in September probably slightly exceeded $0.2 \mathrm{~g} \mathrm{dw} \mathrm{m}^{-2}$.

Mesostigmata had an almost equal abundance around $12000 \mathrm{~m}^{-2}$ on the last three sampling dates. On 18 June their density was roughly half of that. Their biomass ranged between 150 and $200 \mathrm{mg} \mathrm{dw} \mathrm{m}^{-2}$ during the summer. Most of Mesostigmata belonged to predatory Gamasina.

Oribatei had a minimum of $14500 \mathrm{~m}^{-2}$ on 19 July but at other times their numbers ranged from 35000 to $43000 \mathrm{~m}^{-2}$. The maximum biomass of the

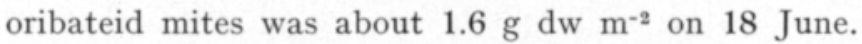

Other Acari (Prostigmata was dominant over Astigmata) were numerous $\left(23000-35000 \mathrm{~m}^{-2}\right)$ but their biomass was negligible compared to the Oribatei and Mesostigmata.

Only one specimen of Opilionae was found and not a single Protura or Diplopoda.

The total biomass of the groups of animals studied was on 19 July about $9.6 \mathrm{~g} \mathrm{dw} \mathrm{m}^{-2}$. This figure does not include animals living beneath the sampling depth, lost during sampling or extraction, or those (Protozoa, Rotatoria, Tardigrada) that were not investigated.

\section{Discussion}

The extraction methods used in this study are considered very efficient (e.g. Huhta and Koskenniemi 1975). Especially the extractor for Lumbricidae is more efficient for small worms than the methods used in many of the earlier studies. The methods have, however, at least the following weak points: the Tullgren funnel is probably not as efficient for softbodied fly larvae as the flotation method (Healey and Russell-Smith 1970), the sampling area $\left(9.51 \mathrm{~cm}^{2}\right)$ was too small for large springtails and no reliable estimates about 
their amounts could be made, and finally, the sampling depth was insufficient for Lumbricidae.

Increase in the number of sampling units reduces the standard error of the mean, but it also raises the costs. It is often necessary to accept a standard error of $10-20 \%$ of the mean in order to keep the work and costs reasonable, especially if the populations have clumped distributions. In the present study most of the S. E. values for upper soil layers remain below $20 \%$ of the mean. Highly aggregated Diptera and Coleoptera larvae are exceptions.

Numerous studies concerning one or more groups of soil animals in grasslands have been published, while very few studies deal with the entire soil fauna. The extensive investigation of Persson and LoHm (1977) deals at species level with all the groups, except Nematoda, included in this study. Their abandoned field (Spikpole) was situated near Uppsala, Sweden. The field had a more distinct and deeper organic layer than my study field (Ruokepuolinen). The vegetation in Spikpole was strongly dominated by Agropyron repens.

The vertical distribution of Enchytraeidae was more even in Spikpole than in Ruokepuolinen. The same phenomenon can be observed also in other taxa. This was probably due to the higher organic content in the deeper layers in Spikpole than in Ruokepuolinen.

In Ruokepuolinen the mean individual size decreased with depth most clearly in Oribatei, Mesostigmata, and Collembola. It is probably not easy for the large individuals of these taxa to penetrate through the dense soil in lower layers (see also HaArløv 1955). The size of the other Acari (mainly Prostigmata) was generally much smaller than that of the other mites and they had a more even vertical distribution. The shape and structure of the Enchytraeidae as well as of the Lumricidae enables them to move easily also in dense and compact soil.

The number of Lumbricidae was smaller $\left(100-130\right.$ vs. $250-330 \mathrm{~m}^{-2}$ in Spikpole than in Ruokepuolinen, but the biomasses were almost equal. The density of the Lumbricidae in this study was high compared to many other temperate grasslands. E.g. Nordström and Rundgren (1973) recorded densities of $29-148 \mathrm{~m}^{-2}$ from southern Sweden, Baltzer (1956) gave values from 6 to $282 \mathrm{~m}^{-2}$ from German pastures and meadows, and GHILARov and Chernov (1974) reported densities of $12-216$ in steppe habitats in USSR. In a grazed pasture in Poland, densities of $83-99 \mathrm{~m}^{-2}$ were found (Nowak 1975). Higher densities have been reported from North Wales (REYNOLdson 1955 ) and on upland localities in England (SVENDSEN 1957), namely 441-484 and $384-470 \mathrm{~m}^{-2}$ respectively. The biomass of the Lumbricidae in Ruokepuolinen was normal to temperate grassland (Nordstöm and RUNDGREN 1973, Nowak 1975, Persson and Lohm 1977). The species composition was typical of a meadow habitat in Finland (Terhivuo and Valovirta 1978).

The number of Enchytraeidae was greater in Ruokepuolinen $\left(50000 \mathrm{~m}^{-2}\right)$ than in Spikpole $\left(18000-34000 \mathrm{~m}^{-2}\right)$, while the biomasses were more equal. Similar $\left(0.6-1.2 \mathrm{~g} \mathrm{dw} \mathrm{m}^{-2}\right)$ or higher values have been reported on Danish pastures (Nielsen 1955 b, 1961) and from England (Macfadyen 1963, Peachey 1963). In southern Finland in meadow forest soil the abundance and biomass 
of the Enchytraeids was markedly lower than in Ruokepuolinen (KAIRESALO 1978).

The abundance of nematodes was about $12000000 \mathrm{~m}^{-2}$ in July. This value is rather high compared to those given by Nielsen (1949), Banage (1963) and WASILEWSKA (1974).

The number of springtails was larger in Spikpole than in Ruokepuolinen. The density was, however, close to the average value of temperate grassland (Wood 1966). The biomass of Collembola $\left(100-200 \mathrm{mg} \mathrm{dw}^{-2}\right)$ is equal or somewhat larger than in Spikpole. This indicates that the specimens were on an average greater in Ruokepuolinen.

Spiders from an ecologically uniform group of predators. Their predation is most intense in the litter-soil interface (KAJAK and JAKUBCZYK 1975). The spiders were slightly more abundant in Ruokepuolinen than Spikpole. Their density $\left(260-542 \mathrm{~m}^{-2}\right)$ accords well with the values reported from unmanaged English grasslands (Bristowe 1939, Duffey 1962, Cherret 1964). In managed grasslands the densities tend to be lower than in natural ones (e.g. KAJAK 1971, Delchev and KaJAK 1974).

In this study mites were divided into three categories, namely Oribatei (Gryptostigmata), Mesostigmata (mostly Gamasina) and other Acari (Prostigmata and to a lesser extent Astigmata). As to numbers, Oribatei and other Acari occurred in greater amounts than did Mesostigmata. The total amount of mites in Ruokepuolinen during the summer was about $60000-100000 \mathrm{~m}^{-2}$. This value is typical of temperate grasslands (Wood 1966, CuRRY 1969, Persson and LoHM 1977). Higher values are obtained mostly from organic soils (Wood 1966). The biomass of Acari $\left(650-1700 \mathrm{mg} \mathrm{dw} \mathrm{m}^{-2}\right)$, especially that of Oribatei, was high compared to the values from Spikpole. Also EngELMAN (1961) and CRossley et al. (1975) reported on lower biomasses in USA, while the results of BLOCK (1966) were of the same magnitude.

The total biomass of the soil animal community (excluding Protozoa, Tardi-

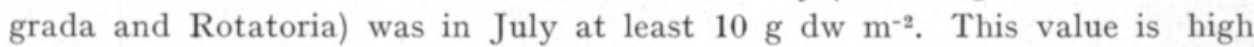
compared to fields of agricultural use. Golesnbiowska and Ryszkowski (1977)

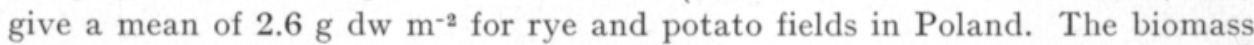
of soil animals in the reserved field was also higher than that in spruce forest in southern Finland (Huhta and Koskenniemi 1975). Especially worms were more abundant in the field, while the biomass of Araneae was greater in forest soil.

The biomass of soil animals at a certain moment indicates very little about their production or energetical signifigance in general. Some comparisons may, however, be of interest. The biomass of above-ground animals was estimated in the same field in 1973 to be about $1 \mathrm{~g} \mathrm{dw} \mathrm{m}^{-2}$ or ten per cent of the biomass of soil animals. The input to the heterotophic subecosystem was estimated at $405 \mathrm{~g} \mathrm{dw} \mathrm{m}^{-2}$ a year from above-ground and at least $345 \mathrm{~g} \mathrm{dw}$ $\mathrm{m}^{-2}$ a year from under-ground parts of the vegetation totalling 750 grams or $13200 \mathrm{~kJ} \mathrm{~m}^{-2}$ per year. There is evidence that in the reserved fields decomposition or heterotrophic respiration is not equal to annual litter production but accumulation of litter does occur (HokKanen and RAATIKAINEN 1977). When the field is left uncultivated and no crop is transferred outside 
the ecosystem there is an excess of organic material for decomposers. And at least during the first five years of secondary succession a balance is not achieved.

Calculated from the data in Table 2, the total amount of organic material in the upmost $15 \mathrm{~cm}$ of soil was about $13.4 \mathrm{~kg} \mathrm{dw} \mathrm{m}^{-2}$ on $19 \mathrm{July}$. This is about $8.9 \%$ of the bulk density of the soil. Most of the organic component is plant material in various stages of decomposition. The amount of roots can be estimated at about $750 \mathrm{~g} \mathrm{dw} \mathrm{m}^{-2}$ (TörmäLÄ and RAatikainen 1976, HokkANEN and RAATIKAINEN 1977) or $5.55 \%$, while the standing crop of soil animals is only of a magnitude of $0.1 \%$ of the organic material in the soil. The amount of bacteria, fungi and algae remains unknown, but probably it does not exceed the biomass of under-ground parts of the vegetation.

The respiration of soil animals, which is often used to indicate their functional importance, was not investigated. Using the results of PERSSON and Loнm (1977), and taking into account the lower temperatures and the greater amount of nematodes in Ruokepuolinen than in Spikpole, the annual respiration by soil animals can be estimated at $850-1050 \mathrm{~kJ} \mathrm{~m}^{-2}$ a year. This is about $6.4-8.0 \%$ of the net primary production. If an annual litter accumulation of $10 \%$ is assumed, the proportion of the studied soil animals of the total heterotrophic respiration in soil and litter would be about $7.2-8.8 \%$.

The trophic structure of the soil faunal community in Ruokepuolinen cannot be analyzed very accurately because in most cases wide taxonomic units including representatives of different feeding categories were used. On the basis of data in the literature about the food of soil animals (e.g. BANAGE 1963, Kaczmarek 1963, Olechowicz 1971, 1974 Healey, and RussellSmith 1971, Waslilewska 1974, Persson and Lohm 1977) the proportion of sapro-/microbivores would be in terms of biomass $90.7 \%$ in July. Belowground herbivores and predators contributed $2.6 \%$ and $6.7 \%$ to the total biomass.

Acknowledgements. I am grateful to Professor Mikko Raatikainen and Assoc. Professor Veikko Huhta for advice and comments. Dr. Hannu Koskela and Assoc. Prof. Veikko Huhta kindly allowed me to use their unpublished data. My thanks are also due to the staff of the Institute of Ecology, Dziekanów Leśny, Poland, for suitable working facilities during the preparation of the manuscript. The study was financially supported by the Finnish Cultural Foundation.

\section{REFERENCES}

Abrahamsen, G. 1973. Studies on body volume, body-surface area, density and live weight of Enchytraeidae (Oligochaeta). Pedobiologia 13:6-15.

Anon. 1976. Kuukausikatsaus Suomen ilmastoon. Ilmatieteen laitos.

BALtzer, R. 1956. Die Regenwürmer Westfalens. Eine tiergeographische, ökologische und sinnephysiologische Untersuchung. Zool. J.buch (Syst.) 84: 355-414.

BANAGE, W. B. 1963. The ecological importance of free-living soil nematodes with special reference to those of moorland soil. J. Anim. Ecol. 32: 133-140.

BLock, W. 1966. Seasonal fluctuations and distribution of mite populations in moorland soils, with a note of biomass. J. Anim. Ecol. 35: 487-503.

Bristowe, W. S. 1939. The Comity of Spiders. Ray Soc. 1:1-228. 
Burges, A. \& Raw, F. (eds.) 1967. Soil Biology. 532 p. London, New York.

Cherretr, J. M. 1964. The distribution of spiders on the Moor House National Nature Reserve, Westmorland. J. Anim. Ecol. 33: 27-48.

Crossley, D. A., Proctor, C. W. \& Gist, C. 1975. Summer biomass of soil microarthropods of the Pawnee National Grassland, Colorado. Amer. Midl. Nat. 93:491-495.

CURry, J. P. 1969. The qualitative and quantitative composition of the fauna of an old grassland site at Celbridge, Co. Kildare. Soil Biol. Biochem. 1:219-227.

DelcheV, K. \& KAJAK, A. 1974. Analysis of a sheep pasture ecosystem in the Pieniny mountains (the Carpathians). XVI. Effect of pasture management on the number and biomass of spiders (Araneae) in two climatic regions (the Pieniny and the Sredna Gora mountains). Ekol. Pol. 22: 693-710.

DUFFEY, E. 1962. A population study of spiders in limestone grassland. J. Anim. Ecol. 31: $571-599$.

EdGAR, W. D. 1971. Aspects of the ecological energetics of the wolf spider Pardosa (Lycosa) lugubris (Walckenaer). Oecologia 7: 136-154.

Edwards, C. A. 1967. Relationship between weights, volumes and numbers of soil animals. Progress in Soil Biology: 585-594. Braunschweig, Amsterdam.

Engelmann, M. D. 1961. The role of soil arthropods in the energetics of an old field community. Ecol. Monogr. 31: 221-238.

Ghilarov, M. S. \& Chernov YU. I. 1974. (In Russian) Summary: Some results of soil-ecological studies in the USSR in frame of the International Biological Program. Izv. Akad. Nauk. SSSR, Ser. Biol. 1974: 563-579.

GolériowsKa, J. L. \& Ryszkowski, L. 1977. Energy and carbon fluxes in soil compartments of agroecosystems. Ecol. Bull. 25: 274-283.

HaArLøv, N. 1955. Vertical distribution of mites and Collembola in relation to soil structure. Soil Zoology: 167-179. London.

Healey, I. N. \& Russell-Smith, A. 1970. The extraction of fly larvae from woodland soils. Soil Biol. Biochem. 2: 119-129.

- 1971. Abundance and feeding preferences of fly larvae in two woodland soils. Organismes du Sol et Production primaire, Proc. $4^{\text {th }}$ Int. Coll. Soil Zool.: 177-191. Paris.

Hokkanen, H. 1979: Pakettipellot, niiden käyttö ja hoito Keski-Suomessa 1974. J. Scient. Agric. Soc. Finl. 51: 25-39,

- \& RAatikainen, M. 1977. Yield, vegetation and succession in reserved fields in Central Finland. J. Scient. Agric. Soc. Finl. 49: 221-238.

Huнт, V. 1972. Efficiency of different dry funnel techniques in extracting Arthropoda from raw humus forest soil. Ann. Zool. Fenn. 9:42-48,

- , Karppinen, E., Nurminen, M. \& Valpas, A. 1967. Effect of silvicultural practices upon arthropod, annelid and nematode populations in coniferous forest soil. Ann. Zool. Fenn. 4: 87-143.

- \& Koskenniemi, A. 1975. Numbers, biomass and community repiration of soil invertebrates in spruce forests at two latitudes in Finland. Ann. Zool. Fenn. 12: 164182.

- , Ikonen, E. \& VilkamaA, P. 1977: Animal succession in artificial soil made of sewage sludge and crushed bark. Ecol. Bull. 25: 573-577.

- 1979. Succession of invertebrate populations in artificial soil made of sewage sludge and crushed bark. Acta Zool. Fenn. in print.

KaczmareK, W. 1963. An analysis of interspecific competition in communities of the insect macrofauna of some habitats in the Kampino Natural Park. Ekol. Pol. 11:421-484.

Kairesalo, P. 1978. Ecology of Enchytareids in meadow forest soil in southern Finland. Ann. Zool. Fenn. 15:210-220.

KAJAK, A. 1971. Productivity investigation of two types of meadows in the Vistula Valley. IX. Production and consumption of field layer spiders. Ekol. Pol. 19: 197-211.

- \& ЈАкивсzук, H. 1975. Experimental studies on spider predation. Proc. $6^{\text {th }}$ Int. Arach. Congr.: 82-85.

Koskela, H. \& HANSKI, I. 1977. Structure and succession in a beetle community inhabiting cow dung. Ann. Zool. Fenn. 14: 204-223. 
LUSSENhop, J. 1971. A simplified canister-type soil arthropod extractor. Pedobiologia 11: 4045.

MAcfadyen, A. 1963. The contribution of the microfauna to total soil metabolism. Soil Organisms: 3-17. Amsterdam.

Nielsen, C. O. 1949. Studies on the soil microfauna 2. The soil inhabiting nematodes. Nat. Jutl. 2: $1-131$.

- 1955 a. A technique for extracting of Enchytraeidae from soil. Soil Zoology: $365-$ 372. London.

- 1955 b. Studies on Enchytraeidae 2. Field studies. Nat. Jutl. 4:1-58.

- 1961. Respiratory metabolism of some populations of enchytraeid worms and free living nematodes. Oikos 12: 17-35.

Nordstöm, S. \& Rundgren, S. 1973. Associations of lumbricids in southern Sweden. Pedobiologia 13: $301-326$.

NowaK, E. 1971. Productivity investigations of two types of meadows in the Vistula Valley. IV. Soil Macrofauna. Ekol. Pol. 19: 129-137.

- 1975. Population density of earthworms and some elements of their production in several grassland environments. Ekol. Pol. 23: 459-491.

O'Connor, F. R. 1962. The extraction of Enchytraeidae from soil. Progress in Soil Zoology: $279-285$.

Olechowicz, E. 1971. Productivity investigation of two types of meadows in the Vistula Valley. VIII. The number of emerged Diptrea and their elimination. Ekol. Pol. 19: $183-196$.

- 1974. Analysis of a sheep pasture ecosystem in the Pieniny Mountains (the Carpathians). $\mathrm{X}$. Sheep dung and the fauna decomposing it. Ekol. Pol. 22: 589-616.

Oostenbrink, M. 1960. Estimating nematode populations by selected methods. Nematology $85-102$.

Peachey, J. E. 1963. Studies on the Enchytraeidae (Oligochaeta) of moorland soil. Pedobiologia 2: $81-95$.

Persson, T. \& Lohm, U. 1977. Energetical significance of the annelids and arthropods in a Swedish grassland soil. Ecol. Bull. 23: 1-211.

Phillipson, J. (ed.) 1971. Methods of Study in Quantitative Soil Ecology. 297 p. Oxford, Edinburgh.

Reynoldson, T. B. 1955. Observations on the earthworms of North Wales. N. West. Nat. 3: $291-304$.

Svendsen, J. A. 1957. The distribution of Lumbricidae in an area of Pennine Moorland (Moor House Nature Reserve. J. Anim. Ecol. 26: 411-421.

Terhivuo, J. \& Valovirta, I. 1978. Habitat spectra of the Lumbricidae (Oligochaeta) in Finland. Ann. Zool. Fenn. 15: 202-209.

TörMÄLÄ, T. 1977. Effects of mowing and ploughing on the primary production and flora and fauna of a reserved field in central Finland. - Acta Agric. Scand. 27: 253-264.

- \& RaAtikainen, M. 1976. Primary production and seasonal dynamics of the flora and fauna of the field stratum in a reserved field in Middle Finland. J. Scient. Agric. Soc. Finl. 48: 363-385.

Wasilewska, L. 1974. Analysis of a sheep pasture ecosystem in the Pieniny Mountains (The Carphatians). XIII. Quantitative distribution, respiratory metabolism and some suggestions on production of nematodes. Ekol. Pol. 22: 651-668.

Wood, T. G. 1966. The fauna of grassland soils with special reference to Acari and Collembola. Proc. N. Z. Ecol. Soc. 13: 79-85.

Ms received April 6, 1979 


\section{Keskisuomalaisen pakettipellon maaperäeläinten runsaus ja biomassa}

TrMo TöRMÄLÄ

Jyväskylän yliopiston biologian laitos, Yliopistonkatu 9 40100, Jyväskylä 10

Seitsemän vuotta paketissa olleen pellon maaperäeläinten runsautta ja biomassaa tutkittiin Jyväskylän maalaiskunnassa vuonna 1974. Näytteet otettiin neljä kertaa kesäkauden aikana. Eri eläinryhmien erotteluun käytettiin viittä menetelmää.

Lukumäärältään runsain ryhmä oli sukkulamadot, joita oli heinäkuussa noin 12 milj. yks./m². Runsaslukuisia olivat myös punkit $(60000-100000$ yks./m²), änkyrimadot (n. $\left.50000 \mathrm{yks} . / \mathrm{m}^{2}\right)$ ja hyppyhäntäiset $\left(30000-60000 \mathrm{yks} . / \mathrm{m}^{2}\right)$. Lierojen tiheys oli $250-320$ yks. $/ \mathrm{m}^{2}$.

Biomassaltaan ylivoimaisesti merkittävin ryhmä oli lierot. Heinäkuussa, jolloin suoritettiin tarkin näytteenotto, lierojen osuus oli $73 \%$ maaperäeläinten kokonaisbiomassasta $(9.6 \mathrm{~g}$ kuivapainona $\left./ \mathrm{m}^{2}\right)$. Seuraavaksi suurimmat osuudet olivat änkyrimadoilla $(5.7 \%)$, punkeilla $(5.5 \%)$, sukkulamadoilla $(4.4 \%)$, kaksisiipiäisten $(3.5 \%)$ ja kovakuoriaisten toukilla $(3.0 \%)$.

Tutkimuksessa selvitettiin myös punkkien, hyppyhäntäisten sekä sukkula- ja änkyrimatojen vertikaalista jakautumista. Punkit ja hyppyhäntäiset olivat selviten keskittyneet maan pintakerroksiin. Kaikissa eläinryhmissä keskimääräinen yksilöpaino pieneni syvemmälle mentäessä.

Pakettipellon maaperäeläimistö osoittautui runsaammaksi kuin metsä- ja viljelysmaan. Erityisesti matojen määrä on pakettipellolla selvästi suurempi kuin metsämailla. 